\title{
Understanding Prescriptive Texts: Rules and Logic as Elaborated by the Mimàmsā School
}

\author{
ELISA FRESCHI \\ Austrian Academy of Sciences, Austria (elisa.freschi@oeaw.ac.at) \\ Agata Ciabattoni \\ Vienna University of Technology, Austria (agata@logic.at) \\ FrANCESCO A. GENCO \\ Vienna University of Technology, Austria (genco@logic.at) \\ BJÖRN LELLMANN \\ Vienna University of Technology, Austria (lellmann@logic.at)
}

The Mimämsā school of Indian philosophy elaborated complex ways of interpreting the prescriptive portions of the Vedic sacred texts. The present article is the result of the collaboration of a group of scholars of logic, computer science, European philosophy and Indian philosophy and aims at the individuation and analysis of the deontic system which is applied but never explicitly discussed in Mimämsä texts. The article outlines the basic distinction between three sorts of principles — hermeneutic, linguistic and deontic. It proposes a mathematical formalization of the deontic principles and uses it to discuss a well-known example of seemingly conflicting statements, namely the prescription to undertake the malefic Śyena sacrifice and the probibition to perform any barm.

Keywords: deontic logic; Mīmāṃsā; language as a means of knowledge; hermeneutics of sacred texts; epistemic value of prescriptive texts; conflicting obligations; proof theory

\section{The Mīmāmsāa School and Its Primary Focus}

Like most Indian philosophical schools, the Mìmāmsā school has a fundamental text and a fundamental commentary on it. The first extant text of the Mīmāmsā school of Indian philosophy, the so-called Pūrva Mìmāmsā Sütra (henceforth PMS ${ }^{1}$ ), can be approximately dated to the last centuries BCE. This has been commented on in the first centuries CE by Śabara in his Śäbarabbāsya (henceforth ŚBh), which together with the PMS constitutes the common ground for all successive developments within the Mīmāmsā̄. ${ }^{2}$ In fact, even after the Mìmāmsā split into the two sub-schools of Prābhākara and Bhāțta Mīmāṃsā (around the 7th c. CE), the PMS and the ŚBh remained the shared foundation of the schools. After having been at the philosophical centre of innumerable debates for centuries, the Mīmāmsā sees its importance declining in contemporary India.

The Mīmāṃsā focuses primarily on the exegesis of sacred texts (called Vedas), and more specifically on their prescriptive portions, the Brāhmanas. These contain sacrificial prescriptions accompanied by mythical

\footnotetext{
- Research for this project has been financed by the WWTF project MA 16-028. Björn Lellmann's research has received funding from the European Union's Framework Programme for Research and Innovation Horizon 2020 (2014-2020) under the Marie Skłodowska-Curie Grant Agreement No. [660047].
} 
aetiologies and further speculations on the ritual. Mīmāmpāa authors considered prescriptions to be the real core of the Brāhmanas and accordingly interpreted the latter categories as subsidiary to prescriptions. This means that the content conveyed by the Vedas as conceived by Mīmāmsakas is, primarily, what must be done (kärya). In other words, the Vedas are an epistemic authority only insofar as they convey a deontic content. ${ }^{3}$

According to Mīmāṃsā authors, the Vedas are authorless. Thus, in order to fulfil their hermeneutical task, Mìmāmsā thinkers could not resort to the intention of the author of the Vedas. Accordingly, they developed nyāyas 'interpretative rules'4 which should guide a reader or listener through a prescriptive text and enable his or her understanding of the text independently of any authorial intention. Such rules have the key purpose of making a text understandable without resorting to the intention of the speaker (either because he or she is distant in time or space, or because, as in the case of the Vedas, the text has an autonomous epistemic or deontic value). The present paper will elaborate on these basic principles and on the way they can turn a text into an epistemic instrument conveying information concerning what one ought to do.

Particular attention will be paid to the deontic principles, since their study allows one to grasp the deontic core of the Mīmāmsā system and the way it interpreted its main purpose, namely the understanding of the goal which the prescriptive portion of the Vedas enjoins. In an attempt to further clarify the meaning of these deontic principles, we will turn some of these into a formal system (basic Mimāmsā deontic logic) ${ }^{5}$.

A benefit of such a formalization is that it enables us to represent certain aspects of the original Mīmāmsā principles and arguments in a clear and unambiguous way, thereby providing a new perspective and formal solutions to controversies discussed by the school. As a case study, we analyze the well-known controversy involving the prescription concerning the Śyena sacrifice, which was supposed to harm the enemies of the performer, and the prohibion to harm any living being.

\section{Rules For Interpreting Deontic Texts}

The Mìmāmsā thinkers were not the only experts on the Vedic rituals. By contrast, there were a number of ritualists who only focused on the praxis of the ritual. Other types of texts, the Śrautasütras and the paddhatis, described the rituals in much more detail than did the Mīmāmsāa texts. But what distinguishes Mìmāṃsā authors is their theoretical interest in the way the Brāhmaṇa texts work. It was this interest which led them to elaborate on and/or systematically implement nyāyas.

Little research has been done on the Mìmāmsāa nyāyas. Apart from Freschi (forthcoming), there is an alphabetic list of these rules in an appendix of Kane's History of Dharmaśästra. Ancient and Mediaeval Religious and Civil Law in India. This however does not distinguish between metarules and topics of each section (adbikarana) of the PMS and ŚBh, so that, e.g., "the meaning of the verbal root" is listed along with proper metarules such as "the maxim of the application of the [procedure as found in the] majority of cases."

More generally, as for the Mīmāṃsā approach to prescriptive texts, several scholars, e.g., Yoshimizu ${ }^{6}$ and Marui, ${ }^{7}$ have noted that the Mīmāmensa has a chiefly deontic focus but they did not attempt any formalization of Mīmāṃsā prescriptions. A first attempt to use mathematical logic in the analysis of the Mīmāṃsā deontic systems is found in Horn's work (Horn 2001) ${ }^{8}$ which used one of the few English translations available of a Mīmāmsā text (Edgerton 1929)9 , and discussed the analysis of prohibitions in Mìmāmsā. But in spite of the interest raised by the opportunity to formalize Mīmāmsāa principles, a comprehensive endeavour in this direction has not been attempted. Indeed apart from Horn's work, which addresses only one Mìmāmsā prescription (and the analysis of a few prescriptions using Standard Deontic Logic in Freschi 2012 ${ }^{10}$ ), no Mīmāṃsā deontic principle has been formalized using the methods of mathematical logic. A possible explanation for this situation is that Mīmāmsā has never been intensively studied by scholars familiar with both Sanskrit and mathematical logic. By contrast, two other central schools of Sanskrit philosophy, namely Nyāya and Vyākaraṇa, have been investigated also by scholars of linguistics and logic (for formal analyses of Navya Nyāya texts, see, e.g., Chakraborty et al. 2008 and especially Ganeri 2008 therein $\left.{ }^{11}\right)$. The studies about such schools have greatly benefited from these investigations. 


\section{Understanding Mìmāmsā nyāyas: Are They Really General Rules?}

The present paper was inspired by the attempt to understand and, as far as possible, re-construct the system of rules which was operating beyond the Mīmāmsā interpretative strategies. The project was developed as a collaboration between the authors of this article and thus involved the elaboration of a shared methodology between philosophers, logicians and philologists. The first necessary step was the discussion of whether such an approach was suitable for the material examined.

Although it is possible that Mīmāṃsā authors merely used an ad hoc approach and thought of specific solutions to each problem instead of general rules for solving classes of similar problems, the structure of the ŚBh suggests a different interpretation. In fact, the ŚBh displays a clear five-fold structure:

1. enunciation of the topic (visaya)

2. enunciation of the problem (samśaya)

3. prima facie view of the problem (purrvapaksa)

4. antithesis to the prima facie view (uttarapaksa)

5. conclusive view (siddhānta)

Steps 3-5 can be repeated several times if the problem is particularly complex and needs a detailed discussion. More important from our point of view is that the upholder of the prima facie view, the upholder of the antithesis and the upholder of the conclusive view (who can be identified with Śabara himself) all resort to the application of rules. In fact, the discussion is mostly all about which rule should be applied and why or why not. Thus, it appears that the Mìmāmsā authors were hoping to create a system that would be independent of the arbitrariness of specific ritualists. Mìmāṃsā authors had in front of them an already existing corpus of ritual prescriptions and most probably also of ritual praxis but they nonetheless tried to detect an order in that corpus that could be described by the set of rules they were developing. During this process they probably also imposed new interpretations on the ritual corpus (which were not always accepted by ritualists; see Daya Krishna 200112).

A further, albeit expost piece of evidence for the general nature of Mìmāmensa rules is the fact that they were massively implemented in the philosophical school of Vedānta and in the field of Dharmaśâstra (jurisprudence). This application is even more significant insofar as it occurred as if the possibility of applying the Mìmāmsā rules outside the context of the specific Vedic injunction in connection with which they were first developed was obvious and did not need to be questioned at all.

\section{Sources for the Identification of Metarules}

The main sources of the present paper are the ŚBh and the PMS. In the case of major disagreements between the two main schools of Pūrva Mīmāmpsā, the texts of their respective founders have also been consulted, namely Kumārila's Ślokavārttika, Tantravärttika and Țpṭ̂ikä, which together comment on the entire ŚBh, and Prabhākara's Bṛhatī, which also comments on the ŚBh but is incompletely transmitted. In some cases, other sources (such as the late primer Mimāmsā Nyāya Prakäśa 'Light on the Rules of Mīmāṃsā,' henceforth MNP, for which see Edgerton 1929) have also been examined in order to find rules which seemed to be presupposed by passages in the PMS and ŚBh. ${ }^{13}$

The first problem for identifying the basic principles, the ones presupposed by the majority of the other rules, is the intersection of at least three sets of principles. These are not explicitly distinguished in Mīmāmsā texts and thus their identification is completely a posteriori and only aims at making the structure of the Mīmāmsā reasoning clearer for its contemporary interpreters: 
1. The hermeneutic principles are needed in order to recognize the boundaries of a given prescription and the way it has been formulated;

2. The linguistic principles are needed in order to discuss the interpretation of linguistic peculiarities of the Sanskrit form of the various prescriptions;

3. The deontic principles are used in order to explain the conceptual structure of the Brāhmanas' obligations.

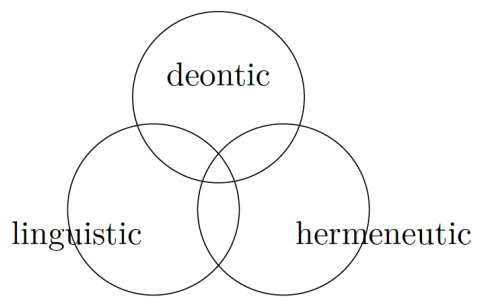

Figure 1: Principles in Mīmāṃsā

The three sets of principles overlap only in part (see figure). In the next sections, we will discuss these three kinds of principles and go into detail about some of them, albeit without attempting to produce a comprehensive list of rules implemented by Mīmāṃsā authors.

\section{$3 \quad$ Hermeneutic Principles}

Hermeneutic principles are those that directly examine the Brāhmaṇa texts and whose significance usually cannot be automatically extended outside them, e.g., to a different corpus of texts. If they are extended, this can be done only with specific caution and only to another textual corpus (as it was done in the case of Mìmāmsā principles being adopted for the Dharmaśāstric jurisprudence). ${ }^{14}$ These principles often refer to a shared background knowledge, e.g., to the way the various classes of Śüdras or Brahmans differ when it comes to the study of the Veda. Mīmāṃsā authors had to develop these principles first of all due to epistemological concerns, namely because they considered the prescriptive portion of the Veda authoritative and thus needed to distinguish such portions of the Veda from the rest.

In order to make sense of complex texts like the Brāhmanas, in which it is not at all easy to distinguish between what belongs to a certain ritual, what to another, and what is just a mythological excursus, Mīmāmsā authors needed to be able to distinguish the boundaries of a given prescriptive passage. Consequently, some basic hermeneutical rules deal with the identification of single prescriptions through syntax as well as through the unity and novelty of the duty being conveyed. The closer one comes to automatizing the process of distinguishing a ritual from a complex textual passage, with intermingled mythological explanations and excursuses, the more complicated the enterprise appears to be, so that the rules easily multiply.

In the following lists we tried to enumerate the cornerstones of the Mīmāṃsā hermeneutic principles. The first list regards the nature of Vedic prescriptions as outlined in these principles.

1. No Vedic prescription can be meaningless. If it appears to be meaningless, it is not a prescription (vidhis cānarthakah kevacit tasmät stutiḥ pratīyeta, PMS 1.2.23). (meaningfulness)

2. Since Vedic prescriptions cannot be meaningless, each prescription must be construed as prescribing a new element (vidhir vā syād apürvatuāt, vādamätram by anarthakam, PMS 1.2.19, see Kataoka 200315). Text passages which seem to only repeat a given content must have a deeper and different meaning, e.g., enhancing the value of the sacrifice to be performed. (novelty) 
3. Each prescription should promote an action (ämnājasya kriyärthatväd änarthakyam atadarthänām tasmäd anityam ucyate, PMS 1.2.1). (duty as action)

4. A prescriptive sentence is identified through the syntactical expectations found in the words that form it and through the individual purpose it conveys (arthaikatväd ekam väkyam, säkänkesam ced vibhäge syät, PMS 2.1.46). Thus, each prescription conveys (only) one piece of deontic information (anyāya anekärthatva, ŚBh ad PMS 2.1.12; sameșu väkyabhedah syät, PMS 2.1.47). (singleness)

5. Each prescriptive text, which may entail several sentences, is assembled around a principal action to be done (conveyed by the principal prescription); all the rest is subsidiary to that action (PMS 1.2.7). A sacrificial substance may lead to a result resting on an already prescribed act, like a king's officer can achieve a certain result only insofar as he relies on the king's authority (bomam áśrito gunah phalam sädhayisyatitit, yathà räjapuruso rājānam äsrito räjakarma karotīti, Vṛttikāra within ŚBh ad PMS 2.2.26). (auxiliarity)

As apparent in the next diagram, we interpret the rule regarding the meaningfulness of the Veda as being presupposed by all other ones, and thus as having the aspect of meta-rules:

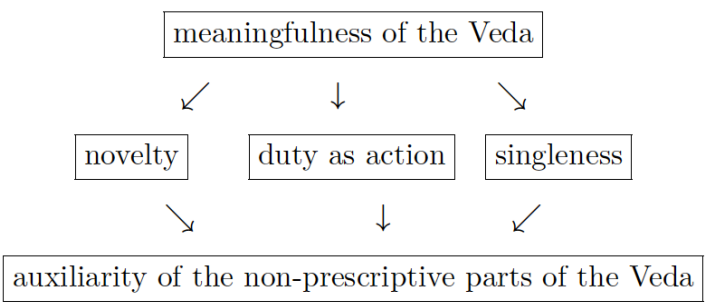

The second list, by contrast, deals with the identification of Vedic prescriptions:

a. The most powerful instrument of knowledge for knowing the meaning of a prescription is what it states directly (śruti), which is more powerful than its implied sense, context, syntactical connection, etc. (nisāidasthapatinyāya PMS 6.1.51-52). (instruments of knowledge)

b. Only what is intended (vivaksita) is part of the prescription. For instance, in the rule "The [sacrificer] should wipe the goblet," the singular in "goblet" does not count, since "goblet" only calls to memory something one already knew (in linguistic terms, a topic), and thus amounts to "the goblet or goblets you already know of, however many they are" (grahaikatvanyayya, PMS 3.1.13-15). By contrast, if the linguistic peculiarities are part of the comment (e.g., they are directly related to the prescribed duty), then they do count. For instance, in the rule "The [sacrificer] should kill a piece of cattle," the singular in "piece of cattle" is significant, since "piece of cattle" is part of what is newly prescribed (in linguistic terms, a comment), and thus the term amounts to "a single piece of cattle" (paśvekatvanyaya PMS 4.1.15, the same as artyadhikarananyāya, PMS 6.4.22). Thus, whether something is intended or not is determined by its link to the sentence's principal duty. (topic vs. comment distinction)

c. Any prescribed action must have a result. If a prescribed action seems to have no result, happiness is to be postulated as the general result (viśvajinnyāya, ŚBh ad PMS 4.3.10). (postulation of result) 


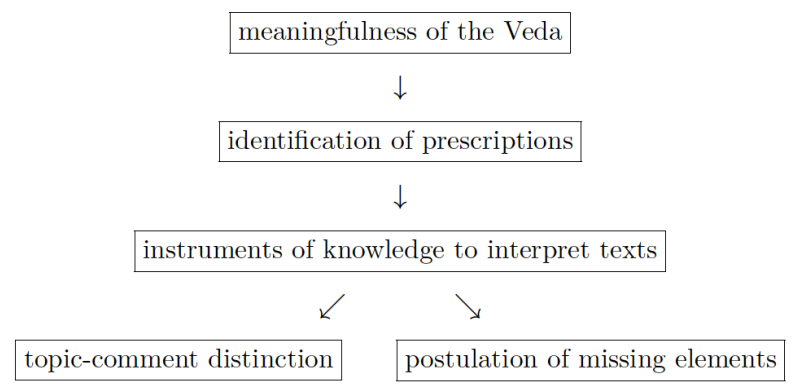

Some of these rules appear characteristic of the Brāhmana hermeneutics (e.g., the strict distinction between the prescriptive parts of the Veda and the non-prescriptive, auxiliary parts). Others may be more general linguistic principles. Yoshimizu (2006) ${ }^{16}$ has, for instance, suggested connecting the principle (b) (immediately above) with the linguistic distinction between topic and comment, and with the consequence that only what is part of the comment is intended, whereas what is part of the topic is not intended. The hermeneutic nature of these principles is shown by the fact that such distinctions disappear if one tries to express them in logical terms.

\section{$4 \quad$ Linguistic Principles}

The linguistic principles can be considered a subset of the hermeneutic ones, but they examine more specifically how Sanskrit works even outside the Veda, e.g., the import of accusative endings. Some of these principles have had a deep impact on Sanskrit linguistic thought, as is especially the case for the following definition of a (prescriptive) sentence:

A prescriptive sentence ${ }^{17}$ is unitary because of the unity of the purpose [it communicates]; if there is syntactic expectancy, there should be a split [in the sentence] (arthaikatväd ekam väkyam, säkänkssam ced vibhäge syät, PMS 2.1.46).

In other words, a single prescriptive sentence is defined through the fact of its conveying a single purpose. If there is syntactic expectation (i.e., if there are elements in the alleged sentence requiring further complements to be understood), this indicates that the sentence must be split into two. The linguistic principles had their origin in the practical need of detecting distinct prescriptions within the continuous text of the Brāhmanas (as discussed also in the previous section), but within the history of Mīmāmsā and subsequently also of Indian linguistic thought it grew into a general rule for the definition of sentences in general.

Similarly important for the history of the methodology of exegesis within Mīmāmsā is the assertion (discussed in ŚBh ad PMS 1.1.1) that words should be interpreted as far as possible according to their ordinary (laukika) meaning and not as technical terms (paribhäsika). The topic of establishing the correct meaning of words is dealt with using various principles (e.g., the aśvakarnanyajya in the Tupțikā ad PMS 4.4.1, similar to the principle enunciated in ŚBh ad PMS 6.1.44-49; the babimyaya in ŚBh ad 3.2.1), all focusing on the idea that the meaning of words in the Veda should be the same as in ordinary language. ${ }^{18}$ Further principles deal with the semantic interpretation of longer passages, as in textual linguistics, e.g., with the conditions for metaphorically interpreting a given prescription.

On the grammatical level, a rule notes that in order to express the meaning of the suffix both the root and the suffix must be uttered together:

The root and the suffix together express the meaning of the suffix (prakrtipratyayau pratyayartham saba brüta iti, ŚBh ad 3.4.13).

Similarly, several rules are dedicated to the semantics of case endings. All such rules pertain to the functioning of morphology. 
Thus, summing up, the linguistic principles include:

- delimitation of sentences,

- textual linguistics,

- the functioning of morphology.

\section{$5 \quad$ Deontic Principles}

Deontic principles were introduced by Mīmāmsāa authors in order to make sense of deontic texts, primarily of the Brāhmanas. As already mentioned, none of the three distinct sets of principles was the object of a systematic description by Mīmāmsāa authors. They were rather implemented whenever needed, so that one is confronted with the task of identifying and classifying them a posteriori. This is particularly true for the deontic principles, since Mìmāmsā authors were chiefly interested in the hermeneutics of Vedic texts and deontic problems per se remained in the background. They, too, must be extracted by scholars from the main hermeneutic enterprise. Accordingly, as yet no adbikarana has been found that discusses only deontic rules, although several sections are dedicated to long and intense debates on the application of one or the other hermeneutic or linguistic principle (alone in the last lines of TV ad 2.1.12 the objector or upholder of the conclusive view evokes six different metarules about the passage in question).

\section{Why Mathematical Logic?}

Given that deontic principles are not clearly outlined but just implemented by Mīmāmsāa authors, a rigorous mathematical formalization would greatly benefit the understanding of them. Indeed, such formalization is exactly meant to provide instruments for the representation, analysis and discussion of such principles. Thus it will be possible to investigate the conceptual core of arguments and principles, distinguishing it from contextual details. Moreover, such a formalization might provide a different perspective on Mīmāṃsā arguments and improve our ability to explain the seemingly conflicting obligations in the Vedas.

However, one might still ask why one should attempt to examine the Mīmāmsā deontic principles precisely according to mathematical logic. This question ultimately deals with the universality of logic. While the investigation of this very interesting issue would exceed the limits of the current paper, which is presenting a casestudy of what happens once such formalizations have been provided (see Gabbay, Abraham, and Schild 2013 for a similar approach to the Talmud ${ }^{19}$ ), a few words on this may nonetheless be appropriate. At the core of logic lies the assumption that, in correct reasoning, conclusions follow from reliable premises via rigorous (and verifiable) inferential steps. It can be easily detected among Mīmāmsā authors that they also (at least implicitly) held this assumption, due to both their theory of inference (anumāna) and their attention to possible violations of it. For instance, Kumārila emphasizes the fact that a text is not epistemically reliable if its beginning is not reliable, even if its whole chain of transmission is reliable. The classical example of this kind of unreliability is that of a chain of truthful blind people transmitting information about colours (andhaparamparānyāya, TV on PMS 1.3.27).

Given that the attitude of the Mīmāmsā school towards rational and inferential reasoning justifies a formal approach to its study, the problem amounts to which system of reasoning (i.e. logic) one should adopt. The best known logic — classical logic_-focuses on assertions, not prescriptions, and thus is clearly not adequate. George Henrik von Wright and many other authors have developed a number of systems of deontic logic exactly in order to address prescriptions (see e.g. Gabbay et al. 2013 for an overview ${ }^{20}$ ). The best known among such systems of logic is Standard Deontic Logic, or briefly SDL. Without going into further details, the main feature of this logic is that it extends classical logic by introducing the additional operator $\mathrm{Obl}$, which stands for "It is obligatory that...," thus allowing the formalization of prescriptive statements.

While SDL is reasonably simple and well-behaved as a form of logic, it is not suited to deal with conflicting obligations (e.g., Gabbay et al. 2013), something that is found in parts of the Vedas; this is one of the points that 
render SDL insufficient to deal with the intricacies of the reasoning employed by Mīmāmesa authors. An example of this is the well-known case of conflict regarding prescriptions arising in connection with the Syena sacrifice, which is broadly discussed by Mīmāṃsā authors (see section "Logic at Work: the Śyena Sacrifice" for its formal treatment in our Mīmāṃsā-inspired logic):

A. "One should not harm any living being" (na bimsyät sarvā bbütäni, a prohibition found in the MBh (MBh 3.203.45, 12.269.5, 12.316.18, all with the form sarvabbütani) and frequently repeated (e.g., Vàcaspati's Tattvavaisárad̄̄ Rāmānuja on BhG 2.19; Madhusūdana on BhG 2.32)

B. "[If one wants to harm his enemy,] one should sacrifice by bewitching with the Śyena" (śyenenäbhicaran yajeta)

The problem is that while the first prescription prohibits any sort of violence, the second enjoins it. Again, without going into details, this intuitive reasoning can be paralleled in SDL, so that from a reasonable formalization of the statements A. and B. we can conclude by the principles of SDL both that it is obligatory to harm a living being and that it is obligatory not to harm a living being. But this is in contradiction with one of the fundamental principles of SDL, which states that nothing can be obligatory at the same time as its negation.

Given that the Mìmāmsā authors embrace the principle of noncontradiction (see section "Formalizations of Mīmāmsā Deontic Rules" below) and that they invested all their efforts in creating a consistent deontic system, we conclude that SDL does not provide an adequate system of reasoning to handle, e.g., the problems associated with the prescription to perform a Śyena sacrifice.

\section{Formalizations of Mìmāmsā Deontic Rules}

Establishing SDL as the default choice for formalizing Mīmāmsaka arguments about prescriptions leads, when applied to the prescription concerning the Śyena sacrifice, to an inconsistent system of reasoning. It thus should not be adopted. But then we are faced with the question of which reasoning system, i.e., logic, to adopt instead. With this in mind, in the present section we are introducing a new logic, which we call basic Mimämsä deontic logic (bMDL for short). This logic, which has been created by formalizing Mīmāṃsā deontic principles, is used in section "Logic at Work: the Śyena Sacrifice" to examine prescriptions related to the Śyena controversy.

In general, when introducing or describing a logic, two levels must be considered, the syntax and the semantics. The former deals with the formal language of the logic under consideration and provides the rules for constructing its formulae, i.e., certain strings of symbols. It does not interpret or give meaning to these symbols. This is done by the semantics, which give a meaning to the formulae and determine their behaviour with respect to some notion of "truth." Once the syntax has been settled, the semantics of the logic is often defined by adding properties (e.g., algebraic properties or Hilbert axioms ${ }^{21}$ ) to the base system. This is the approach we follow for the logic bMDL, which extends classical logic with suitable modal and deontic operators whose properties are directly extracted from first principles, i.e., the Mīmāṃsā deontic rules. These principles are transformed into Hilbert axioms.

We start by defining the formal language of our logic, which is planned to serve as a tool for the formalization of the deontic principles extracted from Mìmāmsā texts. We will first discuss and justify the choices about the non-modal part of the base logic and then introduce and explain the modal operators and present the grammar for the formulae of the language. Apart from propositional variables, $p, q, r, \ldots$ which stand for propositions, the first elements needed for the definition of the language are the propositional connectives. These are the logical symbols, $\wedge$ (conjunction), $\vee$ (disjunction),$\neg$ (negation) $\rightarrow$ (implication),$\top$ (verum), and $\perp$ (falsum). The intuitive meaning of a compound formula built using one of these connectives depends on the meaning of the component formulae. Given two formulae $\varphi$ and $\psi$, the compound formula $\varphi \wedge \psi$ stands for ' $\varphi$ and $\psi$ '; $\varphi \vee \psi$ is for ' $\varphi$ or $\psi$ '; and $\varphi \rightarrow$ $\psi$ is for 'if $\varphi$, then $\psi$.' Given a formula $\varphi$, the formula $\neg \varphi$ is for 'not $\varphi$.' The symbols ${ }^{\top}$ and $\perp$ can be considered connectives of a particular sort; they are not applied to formulae, but are instead treated as formulae themselves. 
The symbol T, also called verum, is regarded as a formula that is unconditionally true, the symbol $\perp$, also called falsum, as one that is unconditionally false.

The first issue that arises is the interpretation of the above language in classical logic, which has been chosen as our base system. It is important to note that when it comes to basic assertive reasoning, the two main alternatives are classical and intuitionistic logic. An exhaustive account of the differences between these two logics would be a complex endeavour and certainly falls outside the scope of this article; one view on the subject is that truth values of formulae in intuitionistic logic refer to the epistemic justification of what is expressed by those formulae, while truth values in classical logic refer to the actual truth of what is expressed. In this sense, for example, in intuitionistic logic it is not licit to infer that something is true knowing only that its negation is not. This is called reductio ad absurdum (or proof by contradiction) and is in contrast allowed in classical logic. More formally, in classical logic if $\neg \neg \varphi$ is true then $\varphi$ must be true, but in intuitionistic logic this does not hold.

Although we could not find stipulative definitions of classical logic principles, when directly confronted with an objection concerning the alleged violation of the law of non-contradiction, ${ }^{22}$ a Mìmāmsā author found in Jayanta's Nyāyamañjari ${ }^{23}$ describes a principle implying the legitimacy of reductio ad absurdum arguments:

As for what has been said [by the Buddhist opponents], namely that "it is illogical that in a single real entity two contradictory aspects simultaneously occur," this is also wrong.

Also, in the case [of our theory] there is no mutual contradiction, because no such [contradiction] is grasped | [In fact,] it is not the case that one knows the one once the other is excluded, as would be the case with mother-of-pearl and silver (where a shiny object can either be an instance of silver or of mother-ofpearl) ||

When there is a contradiction, upon the denial of one [alternative], the other is known [to be true]. But in the topic under consideration it is not so, bence, what is the contradiction?24

The last sentence of this passage indeed says that when a contradiction is considered, denying one alternative makes the other true.

To see why this sentence implies the legitimacy of reductio ad absurdum, consider the contradictory expressions $\varphi$ and $\neg \varphi$. If one of the two is denied there are two possibilities: either $\varphi$ is denied or $\neg \varphi$. If $\varphi$ is denied, then the sentence implies that $\neg \varphi$ is true, thus (identifying the fact that $\varphi$ is denied with the fact that $\neg \varphi$ is asserted) from $\neg \varphi$ follows $\neg \varphi$. This is clearly consistent with classical logic but does not tell us much about the opportunity of adopting a logic that is different. If in contrast $\neg \varphi$ is denied, the same sentence yields that $\varphi$, the other alternative, is true; and this means (again identifying the fact that $\neg \varphi$ is denied with the fact that $\neg \neg \varphi$ is asserted) that from $\neg \neg \varphi$ follows $\varphi$. And this is exactly the reasoning of reductio ad absurdum. In our opinion this provides sufficient reason to adopt classical logic rather than intuitionistic logic as the propositional logic underlying bMDL.

This choice contrasts with one of the few other attempts to reconstruct the deontic logic underlying the traditional reading of a given sacred text, namely the analysis in Gabbay et al. of the deontic logic in the Talmud (Gabbay, Abraham, and Schild 2013). Gabbay et al. based their reconstruction on intuitionistic logic.

Having established the purely assertional basis for our logic, we now consider the additions necessary for capturing the Mīmāmsā reasoning. Since we want to reason about deontic principles, we need to account for various spheres of discourse: the normative one, the one of actual truth and the one of necessity. While the sphere of actual truth is captured by the propositional reasoning of the base logic, i.e., classical logic, to deal with the other spheres, we need to consider modal operators. Therefore, we will add two modal operators to the language: the binary modal operator $\mathrm{Obl}$ ( / ) from dyadic deontic logics and the unary modal operator from alethic modal logics. 
This particular choice of operators is not the only one possible, and hence warrants some discussion. As mentioned in section "Why Mathematical Logic?" the unary deontic operator Obl is usually used to represent an unconditional obligation in a formalized system of norms. By applying this operator to an expression, it asserts that what is meant by the expression is obligatory, with no further requirements. However, since adopting the unary version of the operator $\mathrm{Obl}$ in our case leads to similar complications in the formalization of conflicting obligations, such as those mentioned in the discussion of SDL (section 5), we follow an alternative (but also reasonably standard ${ }^{25}$ ) approach and employ in bMDL the binary (or dyadic) version of Obl. This allows us to impose conditions on the obligation describing the situation in which the obligation holds. In this case the syntactic structure is $\mathrm{Obl}$ ( / ), i.e., the operator is applied to two formulae: one as the injunction, the first, and one as the condition, the second:

The formula $\mathrm{Obl}(\varphi / \psi)$ can accordingly be read as

"it is obligatory that $\varphi$ given that $\psi . "$

Trying to account for the Mīmāmsāa analysis of the Vedic prescriptions, in our formalization the conditions represented by the second formula under the binary operator will usually be of the form "it is desired that...," which identifies the addressee of a given prescription. The standard example for this is "The one who desires heaven should sacrifice with the Full- and New-Moon Sacrifices," which would be formalized as Obl (f_n_m_s/des_heaven), where f_n_m_s stands for performing the Full- and New-Moon Sacrifices and des_heaven for the fact that one desires heaven. To keep the basic Mīmāmsā deontic logic as simple as possible, we have chosen not to further analyze statements of the form "one desires $\mathrm{X}$," but rather to model them using separate propositional variables. While this leaves room for refinement, we believe it to be an appropriate compromise, in particular since Mīmāmsā texts are mainly concerned with prescriptions and not with analyzing the notion of desire.

The chosen operator refers to the normative level in the sense that the truth of a proposition corresponding to a formula in the form $\mathrm{Obl}(\varphi / \psi)$ does not depend in general upon the actual truth of $\varphi$ and $\psi$ at all, but on the status of $\varphi$ and $\psi$ with respect to a corpus of prescriptions.

Finally, the operator for necessity is used in bMDL to formalize auxiliary conditions of general deontic principles. When the relationship between two prescriptions is formally asserted in one of these principles, the correlation between what is mentioned by the parts of the two prescriptions needs to be stronger than mere accident: it must be stable with respect to contingencies and must concern characterizing features of what is meant by the expressions in the formulae. An instance of this difference is, for example, that it is usually contingent whether or not someone harms someone else, but it is necessary that if someone harms a man then they are harming a living being. The operator allows us to assert the necessity of the truth of such an expression: the formula $\varphi$ means that $\varphi$ is true in all relevant circumstances or, in other terms, that it cannot be the case that $\varphi$ does not hold; accordingly we read the formula $\varphi$ as "it is necessary that $\varphi$. ."

To summarize, the formulae of bMDL are inductively defined as follows:

- any propositional variable, $T$ and $\perp$, are formulae of $\mathrm{bMDL}$;

- if $\varphi$ and $\psi$ are formulae of bMDL, then $\varphi \wedge \psi, \varphi \vee \psi, \varphi \rightarrow \psi, \neg \varphi, \quad \varphi$ and $\mathrm{Obl}(\varphi / \psi)$ are formulae of bMDL;

\section{Principles, Axioms and Theorems}

The language defined above provides the necessary tools for formalizing certain selected Mìmāmsā deontic principles. The resulting formulae will be added to classical logic (in the form of Hilbert axioms) to define the logic 
bMDL. The selected principles fix the logical ground on which the basic Mīmāmsā reasoning stands, whereby it is possible that they capture the structural traits characterizing the common logical core of Mīmāmsāa arguments.

To define a first bMDL axiom, we will analyze and attempt to formalize the following excerpt.

When the various (requirements of a given duty), beginning with the origination [of a new duty], are not established by other distinct prescriptions, then [the only prescription available] itself creates the other four prescriptions that are related to it. ${ }^{26}$

This principle affirms that if something is enjoined by a prescription and it has some requirements that are not prescribed separately, then the single prescription is also valid for all the requirements. Hence one could infer that all prescriptions provide sufficient grounds to prescribe all the necessary consequences of what is enjoined, if they fall under the same circumstances. Thus enough grounds are given for accepting the axiom

$$
((\varphi \rightarrow \psi) \wedge \mathrm{Obl}(\varphi / \theta)) \rightarrow \mathrm{Obl}(\psi / \theta)
$$

where $\varphi, \psi$ and $\theta$ can be any formulae. This formula expresses that if it is necessary that $\psi$ is true when $\varphi$ is true then, if $\varphi$ is obligatory, also $\psi$ is obligatory, given the same conditions. Saying that $\psi$ is a prerequisite of $\varphi$ means that it can be the case that $\varphi$ only if it is the case that $\psi$ too, and therefore that if $\varphi$ is true then $\psi$ must be true as well, which is formalized as $(\varphi \rightarrow \psi)$. The operator is used here to guarantee that the correlation between the truth of $\varphi$ and the truth of $\psi$ is not just accidental, but a permanent relationship between what is represented by the two formulae.

Another principle that provides grounds for the previous axiom is the one presupposed by Śabara in the context of the discussion on dharma (i.e., Mīmāmsā itself). ${ }^{27}$ Śabara explains that one cannot start an enquiry into the dharma prior to the study of the Veda, because during the enquiry into the dharma there will be various discussions of Vedic texts, a requirement that can only take place after the Veda has been studied. In a more abstract pattern:

If the obligation to perform $\mathrm{X}$ presupposes the accomplishment of $\mathrm{Y}$, the obligation to perform $\mathrm{X}$ prescribes also Y.

A third principle supporting the acceptance of Axiom (1) is the so-called kaimutikanyaya (a form of the a fortiori argument), which is found at work in instances such as the following passage discussing the fact that even Brāhmanas who commit murder should be executed:

The mention of the word 'Brāhmaṇa' [in the passage specifying that murderers who are Brāhmaṇas should be sentenced to death] has the purpose of [implementing] an a fortiori argument. If one ought to sentence to death even a murderer who is a Brāhmaṇa, then even more so in the case of another [murderer] (that is, one who is not a Brāhmaṇa). ${ }^{28}$

What is attested here is the use of the a fortiori argument for obligations. The reasoning is as follows: If something of a certain generality is enjoined, also all of its necessary consequences are enjoined too, since if $\mathrm{Y}$ is necessarily a consequence of $\mathrm{X}$, either $\mathrm{X}$ and $\mathrm{Y}$ are equivalent, or $\mathrm{Y}$ is an unavoidable aspect of $\mathrm{X}$.

In the endeavour of choosing axioms for the system, another excerpt that has been considered is the following.

Therefore, if these (Smrti ${ }^{29}$ texts) do not have any authority | they must be rejected in all their aspects, and there should not, by contrast, be a 'half-hen'-situation (i.e., a partial acknowledgement of their authority) ||30 
The principle of the half-hen is widely used in different contexts. As is customary for Mīmāmsā principles, it is only used and never defined. Nonetheless, an abstract representation of it could be as follows:

Given that purposes $\mathrm{Y}$ and $\mathrm{Z}$ exclude each other, if one should use item $\mathrm{X}$ for the purpose $\mathrm{Y}$, then it cannot be the case that one should use it at the same time for the purpose $Z$.

This principle stresses the incongruity of enjoining someone to act in contradiction with himself with regard to some object. It is formalized as the axiom

$$
(\psi \rightarrow \neg \varphi) \rightarrow \neg(\mathrm{Obl}(\varphi / \theta) \wedge \mathrm{Obl}(\psi / \theta))
$$

where $\varphi, \psi$ and $\theta$ can be any formulae. It is possible to read this as prohibiting the separate prescription of two contradictory statements under the same conditions.

Finally, the discussion found in the commentary on the chapter about the eligibility to perform sacrifices (adhikāäadhikarana, PMS 6.1) was considered, paying special attention to the passages where the eligibility of the people of different classes is discussed. There, Śabara explains that one should perform sacrifices if one has heard the Vedic injunctions enjoining them. And, since only the people of the higher three classes (out of four classes) can read or hear the Veda, one has to perform sacrifices if one belongs to the higher three classes.

As already stressed, Mīmāmsā authors did not define the principles they were using and rather assumed they could freely use one element or another from a store of available principles shared by all. Nonetheless, Śabara seems to imply the following scheme of reasoning:

If the condition $\mathrm{X}$ and $\mathrm{Y}$ are equivalent, given the duty to perform $\mathrm{Z}$ under the condition $\mathrm{X}$, the same duty applies under $\mathrm{Y}$.

From this one can derive the following axiom:

$$
(((\psi \rightarrow \theta) \wedge(\theta \rightarrow \psi)) \wedge \mathrm{Obl}(\varphi / \psi)) \rightarrow \mathrm{Obl}(\varphi / \theta)
$$

where $\varphi, \psi$ and $\theta$ can be any formulae. This axiom states that a prescription is not only applicable under the mentioned conditions, but also under any conditions that hold in exactly those cases in which the mentioned ones do. If $\psi$ and $\theta$ are necessarily equivalent, it states that what is obligatory if $\psi$ holds, is obligatory also if $\theta$ holds. This last deontic axiom establishes the generality of prescriptions with respect to logically equivalent formulae. The absence of this axiom would make a formalized prescription dependent upon the particular form of the formula that conditions the prescription. This would clearly prejudice the possibility of reasoning effectively about the conditions of the prescription.

After having described the properties of the Obl ( / ) operator in bMDL (i.e. its deontic axioms), we need to settle the properties of the necessity operator. While the properties of $\mathrm{Obl}(/)$ are formalizations of principles extracted from Mīmāmsā texts, the same cannot be done for because, due to their polemics with Buddhist epistemologists, Mīmāmsāā authors do not conceptualize necessity as being separate from epistemic certainty. ${ }^{31}$ However, as discussed above, the introduction of can be derived from the implicit need of a non-accidental link between the variables of a prescription.

The standard and well-established choices for a logic for the alethic operator of necessity are S4 and S5, with S5 being stronger than S4 (see Garson 2014: section 2). ${ }^{2}$ Of these, the concept of necessity represented by S4 seems to match the concept used by Mīmāmsāa authors best. In particular, we have not found any principle motivating the additional properties of S5. Hence, we have chosen to implement the logic S4 adding the following standard axioms to our logic: the axiom $(\varphi \rightarrow \psi) \rightarrow(\varphi \rightarrow \psi)$, usually known as $\mathrm{K}$, which states that if something is necessarily a prerequisite of something else and the latter holds necessarily, then also the prerequisite holds necessarily; the axiom $\varphi \rightarrow \varphi$, usually known as $\mathrm{T}$, which states that whatever is necessary is actually true; 
and the axiom $\varphi \rightarrow \quad \varphi$, usually known as 4 , which can be interpreted as stating that the necessity of a statement is not contingent: if something is necessary, then it is necessarily so. The rule of necessitation (nec) for the

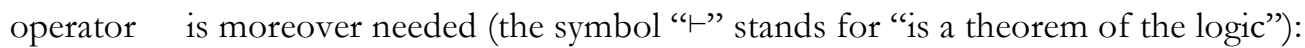

$$
\frac{\vdash \varphi}{\vdash \square \varphi} \text { nec }
$$

where $\varphi$ is an arbitrary formula. The intuition behind this rule is that if a formula is a theorem of logic, then it is not just true, but logically true. Thus, it simply cannot be false, which is another way of saying that it is necessarily true.

Thus, to re-list all of its elements, bMDL is composed of the axioms and rules of classical logic along with axioms (1), (2), (3) and the axioms and rules of the modal logic S4 for the operator .

The following examples show that, though rather simple, bMDL is expressive enough to entail other principles that can be found in Mīmāmsāa, in the sense that formalizing these principles yields bMDL theorems.

Example 1. One such principle is the one that can be extracted from Śabara's discussion of the multiple prescriptions found in the case of the Agnihotra sacrifice (ŚBh ad PMS 10.8.7). There, Śbara settles the issue by noting that if there is already a prescription in a given text passage, all other seeming prescriptions should be considered commendatory statements. In other words,

If there is already a prescription about $\mathrm{X}$, further prescriptions to the same effect are futile.

A formalization of this principle is

$$
((\mathrm{Obl}(\varphi / \theta) \wedge \mathrm{Obl}(\varphi / \theta)) \rightarrow \mathrm{Obl}(\varphi / \theta)) \wedge(\mathrm{Obl}(\varphi / \theta) \rightarrow(\mathrm{Obl}(\varphi / \theta) \wedge \mathrm{Obl}(\varphi / \theta)))
$$

which expresses the logical equivalence of $\mathrm{Obl}(\varphi / \theta)$ and $\mathrm{Obl}(\varphi / \theta) \wedge \mathrm{Obl}(\varphi / \theta)$. This reflects a feature of the conjunction connective $\wedge$ of classical logic: $\psi \wedge \psi$ has the same truth value as the formula $\psi$ itself. The given principle asserts that this holds also for statements of obligation, which conceptually is not completely trivial.

Example 2. Another principle entailed by bMDL is the following (see also section 3, principle 3):

Since the Veda is for the purpose of actions, whatever in it does not aim at actions is meaningless and therefore must be said not to belong to the permanent [Veda]. ${ }^{33}$

This states that the Veda is an authority only insofar as it prescribes actions and each prescription should promote an action. This implies, in particular, that a prescription cannot enjoin someone to realize a logically contradictory state of affairs, because no action can have among its effects such a state of affairs. Thus this principle can be formalized as

$$
\neg \mathrm{Obl}(\perp / \theta)
$$

where $\theta$ can be any formula. The formula states that a logical contradiction cannot be prescribed, or, in other terms, that whatever is unconditionally false cannot be obligatory. The formal proof that the above formula is a theorem of bMDL can be found in Example 1 of Ciabattoni et al. (2015). 


\section{Logic at Work: the Śyena Sacrifice}

Let us now put the logic developed in the last section to work. First, let us remark that while our binary logical operator $\mathrm{Obl}$ ( / ) for obligations now only captures conditional obligations, we would also like to reason about unconditional obligations, i.e., obligations which always have to be fulfilled. We formalize an unconditional obligation to do $\varphi$ with the formula $\mathrm{Obl}(\varphi / T)$, where T is the verum constant (see above, section "Formalizations of Mìmāmsā Deontic Rules"). Since $T$ represents a statement which is always true, the formula $\mathrm{Obl}(\varphi / T)$ can be read as "it is obligatory that $\varphi$ provided anything is the case," thus following that it is unconditionally obligatory that $\varphi$. Following these brief remarks, consider again the Śyena sacrifice (see section "Why Mathematical Logic?"). The formalization in $\mathrm{bMDL}$ of the problematic situation surrounding this example would now be:

(I) "performing violence on any living being" as the atomic proposition harm

(II) "performing the Śyena sacrifice" as the atomic proposition syena

(III) "harming your enemy" as the atomic proposition harm_enemy

(IV) "desiring to harm your enemy" as the atomic proposition desire_harm_enemy

(V) "One should not perform violence on any living being" as the formula Obl ( $\neg$ harm/T)

(VI) "If one wants to harm his enemy, he should perform the Śyena" as the formula Obl (syena/desire_harm_enemy)

In addition we describe the relationship between the atomic propositions harm, syena, and harm_enemy. Since these connections do not only hold accidentally, we describe them as necessary statements using the modality

. They thus take the following form:

(VII) "harming the enemy necessarily entails harming a living being" is formalized as (harm_enemy $\rightarrow$ harm)

(VIII) "performing the Śyena necessarily entails harming the enemy" is formalized as (syena $\rightarrow$ harm_enemy).

Though at first sight 'harm' seems to be at the same time enjoined (by the prescription to perform the Śyena) and prohibited (by the prescription not to perform any harm), as proved in Theorem 4 of Ciabattoni et al. 2015 no contradiction can arise from the formulae (I)-(VIII) when reasoning within the logic bMDL. A formal explanation of the reason why this is the case is provided in section 5 of the same article by using the neighbourbood semantics of bMDL. The basic idea of this kind of semantics is to assign a "meaning" to formulae using suitable mathematical structures, called neighbourbood models. Note that the standard semantics of classical logic, which assigns a value ("true" or "false") to a formula considering only the values of its subformulae, is not adequate for modal logics such as bMDL (see e.g. Chellas 198034). The elements of the neighbourhood model that witnesses the consistency of the formulae (I)-(VIII) represent the possible states of a subject with respect to the concept of adhikara. This concept identifies the addressee of a prescription through their desire for the result of that prescription. In the model there is an element that represents the state in which all applicable prescriptions are fulfilled and no conflict between them occurs. The existence of this state shows that a subject can find a way not 
to transgress any Vedic prescription—and this is possible because, as stressed also by Mīmāmsā authors, it is nowhere said in the Vedas that the Śyena sacrifice must be performed under any condition. Through the use of a dyadic operator our analysis highlights that Vedic prescriptions are commands addressed to those who want to attain a certain desired outcome rather than absolute imperatives.

It now remains to be seen whether this solution maps well with the Mīmāmsā solution of the Śyena conundrum. This necessitates a further restriction, insofar as different solutions of the conundrum were offered by different authors and sub-schools within Mīmāṃsā. Within Prābhākara Mīmāṃsā, the well-known Śālikanātha (9th c.), the main Prābhākara, remarks that the Veda prescribes that no violent act should be carried out (na himsyāt sarvā bhütāni). However, Śālikanātha continues, while the Veda can impart the knowledge about what must be done, this does not limit one's free will to do it or not. And since one wishes to perform an action because one desires its result, if one does not desire to harm anyone, one should not perform the Śyena sacrifice. Thus, the Veda merely lets us known that if we would like to harm someone, we should perform the Śyena sacrifice. It does not say that we must long for such a result. Śălikanātha thus solves the seeming conflict by pointing out that the Śyena prescription only addresses people who fall in the category of "those who desire to harm their enemy." In the Mīmāṃsā terminology the fact of belonging to a determinate category is called adhikāra, as already mentioned, which corresponds to the condition expressed by the dyadic operator introduced in section "Formalizations of Mīmāmsā Deontic Rules." Śālikanātha can thus make the following conclusion:

Hence, only one who desires to harm an enemy is obliged to fulfil such an obligation (i.e., the Śyena one). But, since such a desire is itself forbidden, no one should ever be obliged by it: In the case of an adhikāra related to a wish, the prescription does not say that the sacrifice must be performed, because its performance is accomplished only because of the result. Although the prescription is known as something to be fulfilled and the sacrifice is [known] as the instrument for this (fulfilment of the prescription), nevertheless since in the case of a wish-related adhikāra the sacred text is [only] valid until the accomplishment of a wished result, the prescription does not cause the person to act for its (the prescription's) own fulfilment. For people accomplish the action only because of the result, since they undertake actions because of desire. ${ }^{35}$

In conclusion, the formal solution provided by bMDL matches rather closely the reasoning underlying the solution by Śālikanātha.

\section{Hierarchy of Rules}

\section{Evidence Against a Radical Hierarchy of Rules}

A further problem connected with the nyāyas is the hierarchy of their application. The Mīmāmsā sources do not explicitly state that there is a hierarchy between these rules. Although some rules are clearly directed only to localized cases, such as the understanding of specific terms in certain prescriptions (e.g., rathakāra in PMS 6.1.44), the SBh never denies the general value of individual rules. The discussion in the ŚBh focuses on the legitimacy of the application of given rules, not whether they are overruled by more important ones. But one cannot argue that Mīmāmsāa authors neglected the issue of hierarchies altogether since they do discuss in detail the hierarchical application of the various means of knowledge to ascertain the subordination-links between the various elements prescribed in relation to the same ritual (see MNP: 67-181).

A further means of avoiding the need of an explicit hierarchy is the fact that each obligation only addresses a specific group of people (see above, sections “Formalizations of Mīmāmsā Deontic Rules” and "Logic at Work: the Śyena Sacrifice," for a longer discussion of such dyadic conditions), so that conflicts among obligations can frequently be avoided by taking into account these different addressees (see section "Logic at Work: the Śyena Sacrifice" for the case of the Śyena sacrifice). 
Lastly, the treatment of the vikalpa 'option' (on this, see Freschi 2012: section 4.2.5) also shows that Mìmāmpā authors were not ready to relinquish one prescription in favour of another. They allowed one or the other prescriptions to be temporary abandoned only if this were the only way left to avoid the undesired consequence of seeing the Veda as meaningless (see above, section 3). The discussion of option, in fact, starts with the apparent problem that arises when two different substances (e.g., wheat and barley) are prescribed for the same rite. The way out of this conflict is said to lie in the possibility of opting for one or the other. However, this option is also said to be the least preferable solution of this conflict. Using, for instance, wheat violates the prescription to sacrifice with barley and vice versa (see the yavavarähädhikarana, PMS 1.3.9).

\section{Evidence of a Hierarchy of Rules Based on Their Contents}

Nonetheless, the contents of the prescriptions are hierarchically linked to one another in a way that also influences the relations between the prescriptions. The core element is the principal duty to be realized (typically, that of performing a certain sacrifice). Related to this are the auxiliaries needed to realize this duty, again hierarchically linked to each other according to their relative proximity to the principal duty. ${ }^{36}$ In this sense, a prescription about an auxiliary matter can be superseded by the prescription concerning the principal duty. See, for instance, PMS 3.3.9:

If there is a conflict between the auxiliary and the principal, the [prescriptive force of the] Veda is connected with the principal, since [the auxiliary] is for the sake of that (principal). ${ }^{37}$

This principle is also known as the gunamukhyavratikramanyajya and it states that if there is a conflict between the prescription regarding the principal duty and that regarding a subsidiary, then the first must be implemented, since the subsidiary only subserves the primary duty. In this sense nothing is gained if the latter is implemented, thus generating a violation of the prescription regarding the principal duty.

Similarly, PMS 12.2.27 states:

In the case of a contradiction between a subordinate action and this action's characteristic, [the latter can be overlooked], because it is for the purpose of the former..$^{38}$

The context is that of a complex ritual, in which the characteristic of a subsidiary action, such as the time at which it should be performed, may clash with the action itself and thus should possibly be overlooked. This rule (called angagunavirodhanyāya) is applied to such contexts repeatedly.

A further similar case is the following rule, discussed by Śabara in his commentary on the same sütra:

Among internal and external auxiliaries, the subsidiary which is internal is stronger. ${ }^{39}$

In other words, if there is a conflict between auxiliaries, one should perform the one that is "more internal," i.e., that represents a more internal characteristic of what is to be done. Similar points are expressed also in other rules, such as the padārthapräbalyanyāya mentioned in PMS 1.3.7.

\section{$7 \quad$ Conclusions}

Prescriptive texts require distinct interpretive tools. From its focus on the prescriptive portions of the Vedas the Mīmāmnsā school of Classical Indian Philosophy developed specific rules to correctly understand prescriptive texts. This paper has attempted to analyze and systematize some of these rules. We outlined the basic differences between three sorts of principles_-hermeneutic, linguistic and deontic — and introduced a first formalization of the deontic 
ones. Our formalization led to the introduction of bMDL, a new deontic logic which is used to reason about the seemingly conflicting duties of avoiding harm and performing the malefic Śyena sacrifice.

The present paper is the result of a novel collaboration between scholars of logic, computer science, European philosophy and Indian philosophy. It is our hope that this interdisciplinary dialogue will provide (i) interesting suggestions for developing new tools for the philosophical analysis of various sacred texts and their prescriptions ${ }^{40}$ and (ii) new systems of deontic logic, drawing on ideas elaborated by Mīmāṃsā authors.

\section{Further Directions of Research on Logic and Mimāmsā}

The basic logic bMDL introduced in this paper is only a first step towards mapping the structural elements of the Mīmāṃsā deontic system onto a formal framework. We will hence point out two main directions that further research should or might take. In primis, since important features expressed in the deontic principles cannot yet be captured in bMDL, (i) the logic should be extended in different ways. For instance, it would be interesting to enrich bMDL in order to cover the Mīmāmsā analysis of probibitions as well, formally distinguishing them from obligations (see also Chapter 4 of Gabbay, Abraham, and Schild 2013 for similar work with regard to Talmudic prescriptions).

Moreover, while our preliminary investigation has focused on the easiest (and less expressive) level of logic, namely propositional logic, some deontic principles seem to hint at the need of introducing predicates and quantifiers (thus shifting from propositional bMDL to first-order logic). This is for instance the case of the adhikaranyaya (discussed in PMS 6.1.1-3 and 4-5), which states that the agent of a duty should be the one identified by a given prescription. The basic structure of this rule can be easily represented by means of predicate and quantifiers, namely, "Given the group of people who are agents of duties and the group of people identified by a prescription, it applies for all members of the first group that they are also members of the second."

The language of bMDL might also be extended with temporal operators, as suggested by the principles of the padārthānusamayanyāya (ŚBh ad 5.2.1-2) and the kāndānusamayanyāya (ŚBh ad 5.2.3). Supposing one needs to perform three or more actions on three or more auxiliaries (i.e., sprinkling, threshing and reciting a mantra over rice, barley and millet grains), according to the padarthänusamayanyāya one performs the first action on the first item, then on the second item and then on the third item, and then one repeats the same procedure with the second and the third action. According to the kändanusamayanyaya, in contrast, one performs all three actions on the first item, then moves to the second, performs all three and then moves to the third and performs all three.

A further useful extension could be an additional conjunction connective that, in contrast to the $\wedge$ connective of classical logic (see the example in section 5), asserts that the repetition of a prescription might be, in specific circumstances, meaningful, as stated in the angabhiygastve phalabhiyjastvanyayya, discussed in PMS 10.6.62 and 11.1.15. According to this rule, in fact, if one wants more than one result, one needs to repeat the auxiliary of an optional act (kämya karman), i.e., a sacrifice undertaken because of the desire for the result. However, one does not need to undertake the auxiliaries of a permanent act (nitya karman) again, i.e., a sacrifice undertaken merely because it is due.

Moreover, one might want to extend our system with a mechanism to distinguish subordinate concepts, as hinted by the antarangababirangayor antaraingam balīyah (ŚBh ad PMS 12.2.27; see section 6 above).

Finally, we would like to find a way to handle conflicts between different authorities, as suggested by the vedānam anarthatvaprasange ämnāyatikeramanyāya (ŚBh ad 1.1.1), which prescribes that if there is a conflict between authoritative texts, the Vedas prevail over the Smrtis. Thus, if the consequence of a Smrtti-passage is that a passage of the Veda becomes meaningless, then one ought to transgress that Smrti text. This latter feature is also needed in many applications of artificial intelligence. This intersection also points to the possibility of certain issues discussed in Mìmāmsā leading to the development of crucial concepts in the area of automated reasoning for deontic logics, which in the context of "ethical machines" has never been more important than today (see Chaudhuri and Vardi $201441)$. 
As for the second direction, (ii) while for bMDL we only adopted common metarules of the Mīmāṃsā school (see endnote 13), in order to define logics representing the thought of specific authors, we plan to consider principles that are employed only by those authors; this might help the debate, for example of whether Kumārila's interpretation is more explicative than that of Maṇana.

\author{
Abbreviations \\ BhG Bhagavadgitā \\ MNP Mimāmsānyāyaprakāśs \\ PMS Pūrva Mìmāmsā Sūtra \\ ŚBh Śäbarabhäsya \\ TV Tantravarttika
}

Elisa Freschi studied Indian and European Philosophy at the "Sapienza" University in Rome. Her published work is mostly about Indian philosophy of religion, of language and epistemology (see especially Duty, Language and Exegesis in Präbhäkara Mìmāmsā, 2012; Rule-extension Strategies in Ancient India, 2013; ed. The Reuse of Texts in Indian Philosophy, 2014; ed. Adaptive Reuse: Aspects of Creativity in South Asian Cultural History, 2017). She is currently principal investigator of a project on the theology of Viśiștādvaita Vedānta at the Austrian Academy of Sciences.

Agata Ciabattoni is professor for nonclassical logics in computer science at the Faculty of Informatics of the Vienna University of Technology. She is working on nonclassical logics: their semantics, proof theory and applications to various areas. She is (and has been) involved in many national and international research projects and in 2011 has been awarded a START prize from the Austrian Research Funds (FWF).

Francesco A. Genco graduated in philosophy at the University of Bologna with a bachelor's thesis in Artificial Intelligence and a master's thesis on modal logics. He is currently a PhD student in the LogiCS doctoral college at TU Wien under the supervision of Agata Ciabattoni. He is working on the proof theory and applications of modal and related logics.

Björn Lellmann studied Mathematics at the Albert-Ludwigs Universität Freiburg, and obtained a PhD in Computational Logic from Imperial College London. His work is mainly in structural proof theory for modal and intermediate logics. He is currently a Marie Skłodowska-Curie fellow in the project "PAnaMoL: Prooftheoretic Analysis of Modal Logics" at the TU Wien.

1 The standard edition for PMS and for its commentaries ŚBh and TV is Śrmajjaiminipranitam Mìmāmsādarśanam, ed. Subbāsáastrī (Poona, 1929-1934).

2 In the following, text passages of the SBh commenting on a given aphorism of the PMS will be indicated through the number of the PMS aphorism, e.g. ŚBh ad PMS 1.1.5.

$3 \quad$ For the terms "epistemic" and "deontic" authority, see Józef Maria Bocheński, Was ist Autorität? (Freiburg: Harder, 1974).

$4 \quad$ Mìmāmsā authors speak in this connection of nyàyas, whereas other schools such as the Grammatical one (Vyākaraṇa) use the term paribhäsă in comparable contexts. On the relationship between these terms, see Elisa Freschi, "The Role of paribhāsāas in Mīmāṃsā: Rational Rules of Textual Exegesis," in Meanings out of Rules! Definitions, Functions and Uses of paribhäsāas in Śrautasütras, Vyäkarana, Mìmämsä and Vedānta, ed. Gianni Pellegrini (forthcoming).

5 The reader can refer to the logic conference paper by Agata Ciabattoni, Elisa Freschi, Francesco A. Genco and Björn Lellmann, "Mīmāṃsā Deontic Logic: Proof Theory and Applications," in Automated Reasoning with Analytic Tableaux and Related Methods 9323, ed. Hans De Nivelle (Cham: Springer, 2015), 323-38 for the technical details. 
Kiyotaka Yoshimizu, "Der Geltungsbereich der vedischen Weisung (niyoga) bei den Prābhākaras," Wiener Zeitscbrift für die Kunde Südasiens, Vol. 38, (1994): 485-507.

Hiroshi Marui, "What Prompts People to Follow Injunctions?: An Elucidation of the Correlative Structure of Interpretations of vidhi and Theories of Action," Acta Asiatica, Vol. 57, (1989): 11-30.

Laurence R. Horn, A Natural History of Negation (Chicago: University of Chicago Press, 1989). ed. and transl. Franklin Edgerton, Mimmämsänyāyaprakäśa of Āpadeva (New Haven: Yale University Press, 1929).

Elisa Freschi, Duty, Language and Exegesis in Präbhäkara Mìmämsā: Including an Edition and Translation of Rāmānujācārya's Tantrarahasya, Sāstraprameyapariccheda (Leiden: Brill, 2012).

Jonardon Ganeri, "Towards a Formal Regimentation of the Navya-Nyāya Technical Language I," in Logic, Nayya-Nyāya \& Applications. Homage to Bimal Krishna Matilal, ed. Mihir K. Chakraborty, Benedikt Löwe, Madhabendra Nath Mitra, and Sarukkai Sundar (London: College Publications, 2008), 109-24.

Daya Krishna, "The Mīmāṃsaka versus Yājñika: Some Further Problem in the Interpretation of śruti in the Indian Tradition," in New Perspectives in Indian Pbilosophy (Jaipur: Rawat Publications, 2001), 82-104.

Accordingly, for the present paper, we assumed that a unitary deontic logic for the Mīmāmisā school could be constructed. Further studies will focus on the possibility of identifying different logics in the Prābhākara and in the Bhātța school or in different authors.

Historically, the hermeneutical principles elaborated by Mīmāṃsā authors have been extended to other Vedic texts or to other deontic textual corpora, e.g., to other sets of norms.

Kei Kataoka, “The Mīmāṃsā Definition of Pramāṇa as a Source of New Information," Journal of Indian Philosophy, Vol. 31, (2003): 89-103.

Kiyotaka Yoshimizu, "The Theorem of the Singleness of a Goblet (graba-ekatva-nyāya): A Mìmāmsā Analysis of Meaning and Context," Acta Asiatica, Vol. 90, (2006): 15-38.

vakeya in the PMS consistently refers to a prescriptive sentence, considered as the paradigmatic type of sentence.

That words should have the same meaning in the Veda and in ordinary language is based on the Mīmāmasā.

Dov Gabbay, Michael Abraham and Uri Schild, Principles of Talmudic Logic (London: College Publications, 2013).

eds. Dov Gabbay, John Horty, Xavier Parent, Ron van der Meyden and Leendert van der Torre, Handbook of Deontic Logic and Normative Systems (London: College Publications, 2013).

Hilbert axioms are formulae which are stipulated as always holding and which can be used to derive other "true" assertions of the logic by means of certain specified rules. In particular, such axioms serve as blueprints for constructing "true" assertions by inserting arbitrary formulae for their basic constituents.

The law of noncontradiction, usually formalized as the formula $\neg(\neg \varphi \wedge \varphi)$, is accepted as a logical principle in both classical and intuitionistic logic.

As argued, e.g., by Kei Kataoka (for instance, "A Critical Edition of Bhațta Jayanta's Nyāyamañjarī: The Section on Kumārila's Refutation of the Apoha Theory," The Memoirs of the Institute of Oriental Culture 154, [2008]: 210) and by Elisa Freschi ("The Study of Indian Linguistics. Prescriptive Function of Language in the Nyāyamañjarī and in the Speech Act Theory," in Open Pages in South Asian Studies, ed. Joe Pellegrino [Woodland Hills, California: SASA Books, 2014], 27-62), Jayanta was well versed in Mīmāṃsā and represented the Mīmāmsā point of view reliably.

(Emphasis added.) yad apy abbihitam "itaretaraviruddharüpasamāveśa ekatra vastuni nopapadyate" iti, tad api na samyak. parasparavirodho 'pi nāstīha tadavedanāt | ekabāadhena nänyatra dhïh śuktirajatädivat | | yatra virodho bhavati, tatraikatararüpopamardena rüpāntaram upalabhyate. prakerte tu naivam iti ko virodhärthah (Mīmāṃsā answer found in Bhațta Jayanta's Nyāyamañjarì 5, section 3.1, Kataoka 2010: 193).

See Risto Hilpinen, "Deontic Logic," in The Blackwell Guide to Philosophical Logic, ed. Lou Goble (Maiden: Blackwell, 2001), 159-82, and Lou Goble "Prima facie norms, normative conflicts, and dilemmas," in Handbook of deontic logic and normative systems, ed. Dov Gabbay et al., 241-351.

yatra tütpattyādayo na vidhyantarasiddhās tatra svayam eva svasambandhinām utpattyādicatustayam karoti (Rāmānujācārya, Tantrarabasya, 4th book, section 5.5 in Freschi 2012). 
See ŚBh ad PMS 1.1.1. Similar statements about this principle in general can be found also in ŚBh and TV ad PMS 1.3.33 and in ŚBh ad PMS 7.2.13.

8 brähmanagrahanam tu kaimutikanyāyārtham. ätatāỳ brähmano 'pi vadhyah kimutānya iti, Nārāyaṇa Bhațta’s Vyavahāramāyukha, chapter 24, ātatāyinaḥ, ed. Pandurang Vaman Kane (Mumbaī: Nirṇayasāgara, 1926), 241.

The Smṛtis are a class of texts whose prescriptive contents, according to Mīmāṃsakas, are derived from the Vedas.

tenāsām yadi vā naive kvacid asti pramānatāa | sarvatrāuryähatā vā syān na tv ardhajaratīyatā || (TV ad PMS 1.3.3, p. 85).

Further details at http://elisafreschi.com/2015/03/12/necessity-in-mimamsa-philosophy/

James Garson, "Modal Logic," in The Stanford Encyclopedia of Philosophy, http://plato.stanford.edu/archives/sum2014/entries/logic-modal/, 2014.

ämnāyasya kriyārthatvād änarthakyam atadarthāṇām tasmād anityam ucyate (PMS 1.2.1).

Brian F. Chellas, Modal Logic (Cambridge: Cambridge University Press, 1980).

na ca kāmāadhikeàre niyogo yägasya kartavyatām vadati. phalata eva kartavyatäsiddheh. yady api niyogạ. kartavyatayā pratīyate. tatsādhanatayā ca yāgah. tathäpi kāmädhikāre kāmyamānaphalasiddhiparyantatvāt sästrasya na niyoga eva svasiddhyartham purusam prayunkkte rägākssiptapravrttitvät purusānām phalata eva pravrttisiddhẹ (Śâlikanātha, Rjuvi-

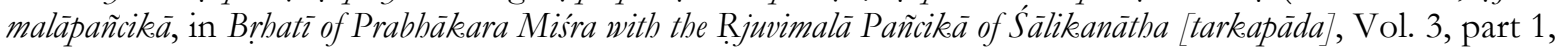
ed. S.K. Ramanatha Sastri (Madras: The University of Madras, 1934), 36, 11. 13-16.

For a detailed discussion of this hierarchical organization, see Freschi 2012: section 4.4.2.

gunamukhyavyatikrame tadarthatvān mukhyena vedasamyogah.

angagunavirodhe ca tädarthyàt.

antarangababirangayor antaraingam balīyah, ŚBh ad PMS 12.2.27.

See http://elisafreschi.com/2015/03/02/deontic-logic-applied-to-sacred-texts/ for a short overview of other studies on deontic logic as applied to traditional interpretations of sacred texts or to sacred texts themselves.

1 Swarat Chaudhuri and Moshe Vardi, "Reasoning About Machine Ethics," POPL OBT (2014). 